Jurnal Penelitian Perawat Profesional

Volume 3 Nomor 2, Mei 2021

e-ISSN 2715-6885; p-ISSN 2714-9757

http://jurnal.globalhealthsciencegroup.com/index.php/JPPP

\title{
TINGKAT STRES PERAWAT TERKAIT ISU COVID-19
}

\author{
Pisga Dwi Lestari Br Pasaribu*, Denny Paul Ricky \\ Fakultas Ilmu Keperawatan, Universitas Advent Indonesia, Jl. Kolonel Masturi No. 288, Cihanjuang \\ Rahayu, Kec. Parongpong, Kab. Bandung Barat, Jawa Barat 40559, Indonesia \\ *pisgapasaribu10@gmail.com (+6282256426637)
}

\begin{abstract}
ABSTRAK
Akibat dari wabah Covid-19 menyebabkan munculnya satu fenomena besar yaitu asosiatif negatif atau stigma terhadap orang yang terinfeksi atau mengalami gejala dari penyakit tersebut. Salah satu penyebab timbulnya diskriminasi atau stigma sosial terhadap orang yang terinfeksi virus ini menimbulkan rasa takut terdapat sesuatu yang belum diketahui. Para petugas kesehatan, terkhusus yang berada di garda terdepan, mengalami tekanan-tekanan ekstrem, terkontaminasi gangguan psikologis yaitu stres serta ,memiliki resiko lebih tinggi untuk terinfeksi, alat pelindung diri yang kurang memadai, jam kerja yang berlebihan, bahkan akan mengalami stigma dari masyarakat. Desain penelitian ini adalah deskriptif kuantitatif dengan wawasan deskriptif. Pengambilan sampel dilakukan dengan non probability sampling dengan teknik random sampling yaitu 75 perawat Rumah Sakit Advent Bandar Lampung yang menjadi subjek atau responden. Instrumen peneltiian menggunakan kuesioner Kesehatan Mental Pada Pandemi Covid-19 ( The Covid -19 Pandemic Mental Health Questionnaire/ CoPaQ) dengan menggunakan google form. $\mathrm{CoPaQ}$ telah diuji validitas dengan expert validity, dengan hasil reabilitas cronbach $\alpha=0,88$. Hasil penelitian menunjukkan bahwa tingkat Stres pada perawat di Rumah Sakit Advent Bandar Lampung berada pada kategori tinggi.
\end{abstract}

Kata kunci: covid-19; perawat; tingkat stres

\section{NURSE STRESS LEVELS RELATED TO COVID-19 ISSUES}

\begin{abstract}
As a result of the Covid-19 outbreak caused the emergence of one major phenomenon, namely negative associative or stigma towards people who are infected or experiencing symptoms of the disease. One of the causes of discrimination or social stigma against people infected with this virus raises fears there is something unknown. Health workers, especially those in the vanguard, experience extreme pressures, are contaminated with psychological disorders, namely Stress and have a higher risk of infection, inadequate personal protective equipment, excessive working hours, and even stigma from society. The design of this research is descriptive quantitative with descriptive insights. Sampling was conducted by non probability sampling with random sampling techniques, namely 75 nurses of Bandar Lampung Adventist Hospital who were the subject or respondents. The instrument of assessment using mental health questionnaire in pandemic Covid-19 (The Covid-19 Pandemic Mental Health Questionnaire / CoPaQ) using google form. CoPaQ has been tested for validity with expert validity, with cronbach reliability results $\alpha=0.88$. The results showed that the level of Stress in nurses at Bandar Lampung Adventist Hospital was in the high category.
\end{abstract}

Keywords: covid-19; nurse; stres levels

\section{PENDAHULUAN}

Awal mula munculnya virus baru yang disebut Coronavirus Disease
(Coronavirus) diakibatkan oleh SARS CoV-2, atau disebut 2019-nCoV, dan tepat pada tanggal 12 Maret dinyatakan 
sebagai pandemi (Febriandi, 2020). SARS-COV-2 atau COVID - 19 diprediksi bermula dari kelelawar lalu terjadi kontaminasi terhadap manusia melalui daging yang di perjual belikan di pasar daging China.(Rosyanti \& Hadi, 2020). World Health Organization melaporkan, tepat pada 30 Agustus 2020, terdapat 24.854.140 orang yang terkonfirmasi kasus virus Corona di berbagai negara dengan jumlah 838.924 kematian (CFR 3,4\%). Benua Amerika dengan kasus terbanyak yaitu 13.138.912 kasus. Berikutnya bagian Eropa terdapat 4.205.708 kasus, benua Asia Tenggara terdapat 4.073.148 kasus , bagian Afrika dan Pasifik Barat masing masing dengan 1.903.547 dan 1.044.513 kasus. Berdasarkan laporan yang diberikan oleh Kemenkes RI , kasus Covid-19 akan terus bertambah dengan 172.053 kasus yang terkonfirmasi. Dengan kasus terbanyak terdapat di DKI Jakarta yaitu sekitar 39.073 kasus (Febriandi, 2020).

Ciri-ciri orang yang terinfeksi Covid-19 biasanya akan menimbulkan gejala umum seperti batuk, sesak nafas dan demam bila berlangsung lama akan menjadi kasus yang berat yaitu respiration acute syndrom, gagal ginjal,pneumonia serta kematian. Jika terkonfirmasi infeksi pasien akan menjalani masa inkubasi selama 14 hari (Dai, 2020). Gejala klinis yang dapat dilihat yaitu batuk, kesulitan bernafas dan demam. Selain itu, ada dengan fatigue, mialgia, sesak memberat, gejala saluran nafas lain dan gejala gastrointestinal seperti diare. Pada beberapa pasien akan timbul gejala ringan tanpa demam sedangkan pada kasus berat dapat menyebabkan syok septik, ARDS, disfungsi sistem koagulasi atau perdarahan, serta asidosis metabolik yang terjadi selama beberapa hari. Namun tidak dipungkiri ada pasien yang mengalami kondisi kiritis bahkan kematian (Otálora, 2020).

Berdasarkan data kasus diatas menunjukan terjadinya peningkatan yang signifikan bahwa kasus Covid-19 akan bertambah secara terus-menerus baik dalam atau luar negeri. Wabah Covid-19 menyebabkan munculnya satu fenomena besar yaitu asosiatif negatif atau stigma terhadap orang yang terinfeksi atau mengalami gejala dari penyakit tersebut. Diskriminasi atau stigma social terhadap orang yang terinfeksi virus ini menimbulkan rasa takut atau kecemasan. Perasaan cemas, takut dan bingung yang dialami dapat dimengerti, tetapi tidak berhak untuk berpikir negatif terhadap perawat, penderita, bahkan keluarga yang memiliki gejala yang sama dengan virus ini, karena hal ini dapat menyebabkan mereka tidak mencari pertolongan sehingga mereka akan menyembunyikan keluhan mereka, dan tidak melakukan perilaku hidup sehat agar tidak didiskriminasi (Dai, 2020).

Menurut pemaparan World Health Organization (2020) menyakatakan pencegahan penularan Covid-19 seperti isolasi mandiri, karantina, atau physical distancing, menyebabkan pasien atau individu berpisah dari keluarga atau orang terdekatnya serta membatasi kebebasan individu. Keadaan ini mengakibatkan seseorang mengalami gangguan kesehatan mental yaitu stres (Susilowati, 2021). Covid -19 penyebab utama masyarakat mengalami diStres. Bentuk depresi terkadang muncul apabila pertahanan emosi seseorang menurun disebut diStres. Misalnya, sedih, kehilangan minat dan putus asa. bentuk kecemasan menimbulkan perasaaan tegang. dan gejala lain seperti perasaan lelah bahkan depresi 
(Susilowati, 2021). Virus Covid-19 mengakibatkan timbulnya efek samping pada psikologis dan mental. Berbagai sektor seperti ekonomi, pendidikan dan industri mengalami kemerosotan akibat virus ini (Sumandiyar \& Nur, 2020). Kegiatan atau aktivitas masyarakat seolah terhenti akibat diberlakukannya social distancing berskala besar untuk menghindari penularan virus ini. Hal ini menimbulkan berbagai gangguan antara lain kecemasan, kepanikan, serta ketakutan atau kekhawatiran (Simanjuntak et al., 2021). Seiring berjalannya waktu kasus Covid-19 semakin bertambah, yang menjadi fenomena besar terhadap para petugas kesehatan terutama perawat dalam menangani pasien Covid-19 secara langsung serta bertambahnya jam kerja, yang membuat perawat dirugikan karena beresiko terpapar infeksi (Nurfadillah et al., 2021).

Permasalahan kesehatan secara luas, mengakibatkan reorganisasi dan restrukturisasi dalam pelaksanaan pelayanan kesehatan untuk menunjang perawatan kritis, perawatan berkelanjutan dan perawatan intensif. Mulai timbulnya kekhawatiran terhadap kesehatan mental serta psikologi dan proses pemulihan pekerja dalam merawat pasien dengan Covid-19. Kewaspadaan semakin meningkat terkhusus dikalangan tenaga kesehatan. Akibat dari terinfeksi yang sangat cepat dari virus ini, gejala yang muncul, kurangnya pengetahuan tentang penyakit, dan tenaga kesehatan profesional mengalami kematian (Rosyanti \& Hadi, 2020).

Para petugas kesehatan, terkhusus yang berada di garda terdepan, mengalami tekanan-tekanan ekstrem, terkontaminasi gangguan psikologis yaitu stres serta, memiliki resiko lebih tinggi untuk terinfeksi, alat pelindung diri yang kurang memadai, jam kerja yang berlebihan, bahkan akan mengalami stigma dari masyarakat. Para petugas juga mengalami hal yang belum pernah dialami, antara lain kurangnya alokasi sumber daya pada pasien, perewatan yang terbatas dan tidak mencukupi kebutuhan serta obatobat tertentu, terjadi ketidakseimbangan antara kebutuhan pasien dan diri sendiri (Rosyanti \& Hadi, 2020).

Menurut survei yang dilaksanakan pada 7.807 pekerja dan menjawab sebanyak $26 \%$ tekanan terbesar terdapat pada pekerjaannya. Ada beberapa faktor penyebab Stres yaitu perbedaan individu,kelompok serta lingkungan. Perbedaan individu dihubungkan dengan keterampilan indvidu dalam mengatasi stres dengan baik sedangkan yang lain merasa kewalahan karena stres. Beberapa faktor perbedaan individu antara lain pengalaman kerja, kepribadian, persepsi dan dukungan social (Tamara \& Wulandari, 2021).

Berdasarkan wawancara dengan beberapa perawat di Rumah Sakit Advent Bandar Lampung yang dilakukan menyatakan perawat mengalami ganggguan mental yaitu Stres. Secara tidak langsung para petugas juga merasa khwatir apabila mereka menularkan infeksi Covid -19 terhadap keluarga atau lingkungan sekitar. Salah satu penyebabnya adalah pengguanan APD seperti masker, goggle, hazmat, hair cap gloves, celemek dan sepatu safety yang mengganggu kegiatan perawatan. Alat Pelindung Diri akan dipakai selama melakukan kegiatan rata - rata 5- 8 jam kerja. Akibat kasus yang terus meningkat menimbulkan Stresor pada tenaga kesehatan. 
Petugas kesehatan, lebih-lebih yang bertugas di tempat pelayanan masyarakat seperti rumah sakit, klink, dan poliklinik lebih rentan untuk terinfeksi virus dan menganggu kesehatan mental (Rosyanti \& Hadi, 2020). Tujuan dilakukannya penelitian ini untuk mengidentifikasi tingkat Stres perawat selama wabah virus Covid-19. Mengidentifikasi hubungan antara tingkat Stres dan isu Covid-19 terhadap perawat . Sehingga peneliti ingin melakukan penelitian dengan tujuan untuk mengidentifikasi tingkat stres perawat terkait isu covid -19".

\section{METODE}

Desain penelitian ini adalah deskriptif kuantitatif dengan wawasan deskriptif. Pengambilan sampel dilakukan dengan non probability sampling dengan teknik random sampling yaitu 75 perawat Rumah Sakit Advent Bandar Lampung yang menjadi subjek atau responden. Instrumen peneltiian menggunakan kuesioner Kesehatan Mental Pada Pandemi Covid - 19 ( The Covid -19 Pandemic Mental Health Questionnairel $\mathrm{CoPaQ}$ ) dengan menggunakan google form. $\mathrm{CoPaQ}$ telah diuji validitas dengan expert validity, dengan hasil reabilitas cronbach $\alpha=0,88$. Sebelum mengisi kuesioner,responden terlebih dahulu diminta untuk mengisi Inform Consent sebagai tanda bahwa responden bersedia berpartisipasi dalam penelitian ini tanpa adanya paksaaan dan diambil secara acak di setiap layanan kesehatan. Faktor-faktor yang digunakan dalam penelitian ini adalah tingkat Stres para perawat yang memengaruhi gangguan mental perawat yaitu Stres. Subjek penelitian adalah perawat, yang dipercaya untuk mencegah, menangani dan merawat pasien di ruang isolasi rumah sakit, serta ruang gawat darurat darurat dan yang sedang bekerja di Rumah Sakit Advent Bandar Lampung. Subjek penelitian ini adalah perawat yang bekerja di Rumah Sakit Advent Bandar Lampung yang bertugas di beberapa department. Kriteria inklusi responden adalah berusia 21 tahun keatas, dan perawat yang bekerja di Rumah Sakit Advent Bandar Lampung. Penelitian ini telah disetujui oleh Komite Etik Rumah Sakit Advent Bandar Lampung dengan Nomor 04/KEPKRSABL/III/2021.

Dalam menentukan klasifikasi tingkat Stres pada $\mathrm{CoPaQ}$, nilai mean diinterpretasikan menjadi 5 kategori, yaitu mulai dari kategori sangat rendah dengan nilai mean 0\%-19,99\%, kategori rendah dengan nilai mean 20\%-39,99\%, kategori cukup dengan nilai mean $40 \%$ $59,99 \%$, kategori tinggi dengan nilai mean 60\%-79,99\%, dan kategori sangat tinggi dengan nilai mean $80 \%-100 \%$.

\section{HASIL}

Tabel 1 menjelaskan karakteristik demografi responden menunjukkan bahwa sebagian besar responden sebanyak 60 responden adalah perempuan, dan 15 responden adalah laki-laki, dengan rentang usia terbanyak pada usia 30-39 tahun yaitu sebanyak 30 responden. Berdasarkan data tingkat pendidikan responden terbanyak yaitu pada tingkat pendidikan DIII sebanyak 26 responden. Tabel 2 menunjukkan nilai mean $71,85 \%$ yang diartikan bahwa tingkat Stres perawat Rumah Sakit Advent Bandar Lampung berada pada tingkat Stres tinggi. 
Tabel 1.

Karakterisitik Responden $(\mathrm{n}=75)$

\begin{tabular}{lcc}
\hline \multicolumn{1}{c}{ Karakteristik } & $\mathrm{f}$ & $\%$ \\
\hline Jenis Kelamin & 15 & 20 \\
Laki-laki & 60 & 80 \\
Perempuan & & \\
\hline Usia & 19 & 25,3 \\
$21-29$ & 30 & 40 \\
$30-39$ & 23 & 30,7 \\
$40-49$ & 2 & 2,7 \\
$50-59$ & 1 & 1,3 \\
$60-69$ & 0 & 0 \\
70 & & \\
\hline Pendidikan & 26 & 34,7 \\
DIII & 22 & 29,3 \\
S1 & 2 & 2,7 \\
S2 & 25 & 33,3 \\
Profesi Ners & & \\
\hline
\end{tabular}

Tabel 2.

Hasil Nilai Mean Tingkat Stres Responden $(n=75)$

\begin{tabular}{ccc}
\hline Responden & Mean & Std. Deviation \\
\hline 75 & 71,85 & 23,373 \\
\hline
\end{tabular}

\section{PEMBAHASAN}

\section{Karakteristik Responden}

Berdasarkan hasil penelitian dari tabel 1 didapati wanita memiliki tingkat Stres yang lebih tinggi dibandingkan lai-laki dengan jumlah 60 orang present $80 \%$. García-Fernández et al., (2021) menyatakan penelitian wanita memiliki risiko lebih tinggi mengalami Stres dibandingkan laki-laki. Hal ini kemungkinan disebabkan oleh karena wanita memiliki peran utama sebagai pengasuh keluarga dan kerentanan yang lebih besar terhadap isolasi social. Hal ini berdasarkan pernyataan Spagnolo et al., (2020) dimana wanita memiliki sistem respon Stres yang meningkat respon endokrin, afektif, dan gairah Stres. Maka hal ini menyebabkan wanita lebih rentan mengalamin Stres.

Semakin bertambah usia seseorang maka akan semakin besar kemungkinan mengalami Stres. Seorang pekerja dengan usia lebih tua cenderung memiliki kondisi kesehatan yang kurang baik dibandingkan dengan seorang pekerja dengan usia yang lebih muda (Zulkifli et al., 2020). Pada era pandemic Covid-19, usia tua memiliki risiko penuluran lebih besar oleh karena memiliki imun yang lebih rentan. Maka dari itu, untuk usia yang lebih rentan perlu diperhatikan jam kerja untuk membantu mengurangi risiko penularan dan tingkat Stres yang dialami.

Sikap seorang menghadapi Stres dipengaruhi oleh tingkat pendidikan yang ia miliki. Semakin tinggi tingkat pengetahuan seseorang, maka individu diharapkan mampu menghadapi situasi dan kondisi untuk mengurangi kecemasan, sehingga diharapkan mampu meminimalisir tingkat Stres. Seseorang yang memiliki pengetahuan yang rendah memiliki kecenderungan 
sulit untuk menerima dan memahami informasi, sehingga akan merasa tidak peduli terhadap informasi yang diterima dan timbul perasaan informasi yang didapatkan tidak diperlukan (Kusnanto et al., 2019). Stres yang dialami seseorang kemungkinan semakin rendah oleh karena semakin tinggi pengetahuan yang dimiliki, dan diharapkan dengan tingginya latarbelakang pendidikan maka akan tinggi juga pengetahuan yang dimiliki (Sihombing et al., n.d.).

\section{Hasil Nilai Mean Tingkat Stres Responden}

Berdasarkan data yang didapatkan peneliti, tingkat Stres yang dialami perawat Rumah Sakit Advent Bandar Lampung berada pada 71,85\% dengan interpretasi tingkat tinggi. Rasa takut terinfeksi virus yang memiliki potensi kematian merupakan sumber timbulnya kekhawatiran yang dapat memicu Stres (Arnetz et al., 2020). Karakteristik menular COVID-19 yang mempengaruhi pernapasan, tidak menutup kemungkinan dapat menular kepada perawat dengan kontak yang sering dengan pasien yang terinfeksi atau berpotensi terinfeksi. Maka hal ini menimbulkan kekhawatiran tertular penyakit itu sendiri dan berpotensi menularkannya kepada orang lain.

Menurut Nurfadillah et al., (2021) ada beberapa factor yang memengaruhi kesejahteraaan mental pada perawat di masa pandemic yaitu factor individu yang meliputi umur, gender, sudah menikah dan mempunyai orangtua lansia, mempunyai anak, serta yang bertugas di rumah sakit atau tempat yang lebih beresiko menimbulkan infeksi virus Covid-19, sementara itu ada factor keadaan yang memengaruhi kesejahteraan mental perawat antara lain resiko terpapar virus Covid-19, kurangnya dukungan social atau stigma dari masyarakat serta pengguaan APD. Hal ini berhubungan dengan paparan yang disampaikan dalam penelitian (Handayani et al., 2020) banyak tenaga kesehatan khususnya perawat memiliki kekhwatiran akan penularan infeksi virus Covid-19 bukan hanya karena kekurangan sediaan alat tetapi juga dari pasien yang terpapar virus Covid19 melalui droplet yang ada di udara, dan tanpa diketahui oleh perawat pada saat memperbaiki, memakai, serta melepas APD rentan untuk terinfeksi virus Covid-19.

Tingkat Stres masing-masing individu penting untuk diperhatikan, guna untuk mencapai keefektifan hasil kerja dan untuk mengatasi risiko Stres yang tidak diharapkan. Melihat hasil penelitian yang ditemukan peneliti, hal ini berarti perlu peningkatan koping Stres untuk mengurangi tingkat Stres dan meningkatan hasil kerja yang efektif dari perawat.

\section{SIMPULAN}

Hasil penelitian menunjukkan bahwa tingkat Stres pada perawat di Rumah Sakit Advent Bandar Lampung berada pada kategori tinggi.

\section{DAFTAR PUSTAKA}

Arnetz, J. E., Goetz, C. M., Arnetz, B. B., \& Arble, E. (2020). Nurse reports of Stresful situations during the COVID-19 pandemic: Qualitative analysis of survey responses. International Journal of Environmental Research and Public Health, 17(21), 1-12. https://doi.org/10.3390/ijerph1721 8126

Dai, N. F. (2020). Stigma Masyarakat Terhadap Pandemi Covid-19. Prodi Ilmu Keperawatan 
Universitas Indonesia Timur, 6673.

Febriandi. (2020). Tinjauan Pustaka COVID-19:Virologi, Patogenesi, Dan Manifestasi Klinis. Jurnal Medika Malahayati, Vol 4, No 3. http://journals.sagepub.com/doi/1 $0.1177 / 1120700020921110 \% 0$ Aht tps://doi.org/10.1016/j.reuma.201 8.06.001\%0Ahttps://doi.org/10.10 16/j.arth.2018.03.044\%0Ahttps://r eader.elsevier.com/reader/sd/pii/S 1063458420300078 ?token $=\mathrm{C} 039$ B8B13922A2079230DC9AF11A 333E295FCD8

García-Fernández, L., Romero-Ferreiro, V., Padilla, S., David LópezRoldán, P., Monzó-García, M., \& Rodriguez-Jimenez, R. (2021). Gender differences in emotional response to the COVID-19 outbreak in Spain. Brain and Behavior, 11(1), 7-11. https://doi.org/10.1002/brb3.1934

Handayani, R. T., Kuntari, S., Darmayanti, A. T., Widiyanto, A., \& Atmojo, J. T. (2020). Factors Causing Stres in Health and Community When the Covid-19 Pandemic. Jurnal Keperawatan Jiwa, $\quad 8(3), \quad 353$. https://doi.org/10.26714/jkj.8.3.20 20.353-360

Kusnanto, K., Sundari, P. M., Asmoro, C. P., \& Arifin, H. (2019). Hubungan Tingkat Pengetahuan Dan Diabetes Self-Management Dengan Tingkat Stres Pasien Diabetes Melitus Yang Menjalani Diet. Jurnal Keperawatan Indonesia, 22(1), 31-42. https://doi.org/10.7454/jki.v22i1.7 80

Nurfadillah, Arafat, R., \& Yusuf, S. (2021). Gambaran Faktor Yang
Mempengaruhi Kesehatan Mental Perawat Pada Masa Pandemi Covid-19: Literatur Review. Jurnal Keperawatan, 13, 40-46.

Otálora, M. M. C. (2020). Yuliana. Parque de Los Afectos. Jóvenes Que Cuentan, 2(February), 124137.

https://doi.org/10.2307/j.ctvzxxb1 8.12

Rosyanti, L., \& Hadi, I. (2020). Dampak Psikologis dalam Memberikan Perawatan dan Layanan Kesehatan Pasien COVID-19 pada Tenaga Profesional Kesehatan. Health Information: Jurnal Penelitian, 12(1), 107-130. https://doi.org/10.36990/hijp.vi.19 1

Sihombing, H. W., Septimar, Z. M., Sihombing, H. W., \& Perawat, P. (n.d.). Hubungan Pengetahuan Perawat tentang COVID-19 dengan Tingkat Stres dalam Merawat Pasien COVID-19. 6(1), 22-30.

Simanjuntak, G. V., Pardede, J. A., \& Sinaga, J. (2021). Mengelola Stres di Masa Pandemi Covid-19 Dengan Hipnotis Lima Jari. 4(1), 54-57.

Spagnolo, P. A., Manson, J. A. E., \& Joffe, H. (2020). Sex and Gender Differences in Health: What the COVID-19 Pandemic Can Teach Us. Annals of Internal Medicine, 173(5), 385-386. https://doi.org/10.7326/M20-1941

Sumandiyar, A., \& Nur, H. (2020). Membangun Hubungan Sosial Masyarakat di Tengah Pandemi Covid-19 di Kota Makassar. 7481. 
Susilowati, D. W. (2021). Dampak Psikologis Akibat Covid-19 pada Masyarakat Indonesia. Wacana, 13(1), 104-111. https://doi.org/10.13057/wacana.v $13 \mathrm{i} 1.193$

Tamara, T. A., \& Wulandari, R. D. (2021). Perbedaan Individu Sebagai Faktor Penyebab Stres Kerja pada Tenaga Kesehatan Akibat Pandemi Covid-19: Narrative Literature Review Individual Differences as a Work Stres Factors Causing on Healthcare Personnel Due to the Covid-19 Pandemic: A Narrative
$L$. 17(1). https://doi.org/10.19184/ikesma.v $17 i 1.21892$

Zulkifli, Z., Rahayu, S. T., \& Akbar, S. A. (2020). Hubungan Usia, Masa Kerja dan Beban Kerja Dengan Stres Kerja Pada Karyawan Service Well Company PT. ELNUSA TBK Wilayah Muara Badak. KESMAS UWIGAMA: Jurnal Kesehatan Masyarakat, 5(1), 46. https://doi.org/10.24903/kujkm.v5 i1.831 